\title{
Knocking at the door? The women's portfolio from Labor to the Coalition
}

Susan Harris Rimmer, Asia-Pacific College of Diplomacy, Australian National University susan.harris-rimmer@anu.edu.au

Marian Sawer, School of Politics and International Relations, Australian National University marian.sawer@anu.edu.au

\section{ABSTRACT}

The lead item in the Coalition women's policy for the 2013 federal election was the return of the Office for Women to the Department of Prime Minister and Cabinet. Since 2004 it had been located 20 kilometres from the heart of government, relegated to a line department dealing with family and community services. Did its return from exile indicate a renewed commitment to whole-of-government gender assessment of policy?

This paper assesses the directions taken by women's policy under the Rudd and Gillard Governments as compared with the new Coalition Government. It examines machinery of government arrangements for gender mainstreaming at national and intergovernmental levels. The paper concludes with analysis of why Australia's major parties now more readily articulate gender equality objectives in areas such as international peacekeeping and development assistance than in domestic economic and social policy outside the gender-based violence area.

\section{Introduction}

In 1973 Australia became the first country to appoint a women's adviser to the Prime Minister, to advise on how government could better serve the needs of women. What soon followed was government machinery to ensure policy proposals were analysed for gender impact, both in line departments and at the centre when Cabinet submissions arrived. During the 1970s and 1980s Australia was regarded as being in the forefront of the development of gender assessment of policy through its wheel model of women's policy machinery. This was particularly the case when this whole-of-government machinery became the basis for 'gender-responsive budgeting', requiring even reluctant economic departments, to account for the gender impact of their policies and programs. This was regarded as a good-practice model of what became known internationally from 1995 as 'gender mainstreaming' - the establishment of an overall policy objective of advancing gender equality, routine gender analysis of policy to ensure conformity with 
this objective and indicators to monitor progress. Apart from advancing gender equality objectives, routine disaggregated analysis of policy proposals had the benefit of improving the policy process by reducing unanticipated policy outcomes.

Having been an early starter in the development of women's policy machinery, progress faltered in the 1990s and Australia fell behind many other countries in terms of the implementation of gender mainstreaming (Sawer 2007). During this period there was a retreat from high-profile women's policy launches during election campaigns and central women's policy co-ordinating agencies were moved away from the centre of government. There has been no overall national plan or roadmap for gender equality since the National Agenda for Women of 1988-1992. Moreover Australia has never developed parliamentary bodies to oversee implementation of gender mainstreaming, like those that are found in Europe and in Canada (for a database on these see IPU 2014).

In this article, we shall take a closer look at developments in the 'women's portfolio' under the Rudd, Gillard Governments and in the transition to the Abbott Government. Due to the extensive attention already given to misogyny and discursive issues in this period (for example, Summers 2013a; Trenoweth 2013), we have chosen to focus more in this article on the policy frameworks, architecture and machinery of government reforms. We adopt a new institutionalist approach, stressing the importance of institutionalised gender equality mandates for cumulative achievement in this area, but also the constraints imposed by shifting discursive environments and their effects on political will (McBride and Mazur 2010). For our evidence we draw on 'grey literature' as well as interviews with senior officials and participant observation by both authors.

Our underlying research question concerns why both the Labor and Coalition parties are now more comfortable in articulating gender equality objectives in areas such as international peacekeeping and development assistance than in domestic economic and 
social policy. We begin with an overview of gender equality policy frameworks under the Rudd, Gillard and Abbott Governments, with an emphasis on intergovernmental initiatives. We then move on to examine specific policy sectors, first under Labor and then under the Abbott Government. We devote some specific attention to the relationship of these governments to non-government organisations and to broader trends in the political representation of women. We conclude with a number of possible explanations for why governments have become less comfortable with analysis of domestic policy for gender outcomes but still supportive of international gender equality objectives.

\section{Gender equality frameworks under the Rudd, Gillard and Abbott Governments}

By the time of the Rudd and Gillard Governments the major political parties had become less inclined to issue women's policies as part of their election campaigns (see Table 1). The Labor Party, which had produced strong women's policies in the 1980s, became persuaded that such policies were likely to lose votes in its blue-collar heartland. There were no follow-ups, for example, to the National Agenda for Women, the five-year plan launched by the Hawke Government in 1988. From the 1990s not only were the major parties less likely to produce a women's policy as part of their campaign, when one was produced it was often slipped onto a party website rather than being launched in the traditional way. For example, in 2007 the Coalition released its policy onto its website two days before the election while in 2010 the Labor policy was released onto its website the day before the election. In line with this forgetfulness about gender, the women's portfolio was missing from the Gillard Government's initial announcement of portfolios following the 2010 election.

Table 1. Women's policies at federal elections 2007-2013

\begin{tabular}{|l|l|l|}
\hline & Coalition & Labor Party \\
\hline 2007 & Yes & No \\
\hline 2010 & No & Yes \\
\hline 2013 & Yes & No \\
\hline
\end{tabular}


The lack of comprehensive women's policies meant that an overall framework for achieving gender equality was missing from these governments. At the intergovernmental level, where much decision-making takes place, there were some efforts to develop a national gender equality framework during a time when most jurisdictions had Labor governments. In 2008 the Ministerial Conference on the Status of Women (MINCO) set up a working party to develop national gender equality indicators and after these were approved, the Australian Bureau of Statistics (ABS) was commissioned to develop them. Gender Indicators Australia (ABS Cat. No. 4125.0) was first released in 2011 and annual reports have been released subsequently. However the MINCO did not achieve its aim of having these indicators adopted into the work of all government decision-making bodies, including COAG.

Moreover, the MINCO, in existence since 1991, came to an end in 2011 as part of COAG reform. It was replaced by a short-term Select Council on Women's Issues (2011-13), again with the development of a national gender equality framework as one of its terms of reference. Despite commitment to working with other ministerial councils on such a framework, partisan differences made progress difficult. Instead, in order to achieve some accountability for gender outcomes, the Select Council recommended that the COAG Reform Council (CRC) report on such outcomes from Commonwealth-State agreements. The COAG Reform Council presented one such report (CRC 2013) before it too was abolished in 2014. The abolition of these intergovernmental bodies meant there were no longer any arrangements in place to promote a national framework on gender equality. The officials' body, the Standing Committee of Women's Advisers, which had been meeting regularly since 1978 and servicing the Ministerial body since 1991, also ceased regular meetings.

The recent loss of intergovernmental bodies responsible for promoting gender equality and applying a gender lens to policy mirrored the earlier loss of many such bodies within Australian governments- for example the Women's Bureau (1963-1997) within the 
federal employment portfolio. Despite theoretical assumptions about institutional 'stickiness', such feminist institution-building has proved vulnerable to discursive shifts within Australian governance as neoliberal frameworks have gained influence. This has been particularly true of women's agencies within policy areas (Andrew, 2013; MAWM 2013). Women's services have proved more resilient, although they too have been coming under threat in the second decade of the $21^{\text {st }}$ century.

\section{The Rudd, Gillard Governments, gender equality policies}

Despite the lack of an overarching gender equality framework, there was progress under the Rudd and Gillard governments in specific policy sectors. In the gender-based violence area the peak bodies representing women's sexual assault and domestic violence services were brought back into the policy process after being frozen out under the Howard Government. As Minister, Tanya Plibersek established a National Council to advise on gender-based violence policy which included members of domestic violence and sexual assault peak bodies as well as a range of other non government organisations (NGOs). ${ }^{1}$ After extensive consultations and roundtables it produced the comprehensive Time For Action report launched in 2010 with bipartisan support.

Subsequently COAG and all its component governments adopted the National Plan to Reduce Violence against Women and their Children 2010-2022 (Commonwealth of Australia 2012). This was the most comprehensive intergovernmental and cross-sectoral plan to date, laying out a series of steps to prevent and respond to violence. As with previous Labor Government plans, gender-based violence was understood as arising from and reinforcing systemic gender inequalities in the distribution of power and resources. It has been argued that this was in contrast to the preceding Howard

\footnotetext{
${ }^{1}$ For backgrounds of members, including those with expertise in relation to Aboriginal and immigrant women: http://www.formerministers.dss.gov.au/1885/nat_council_violence_26may08/
} 
Government's Partnerships against Domestic Violence (PADV), which 'individualized the problem and focused increasingly on perpetrator programs' (Chappell and Curtin 2013: 34). One continuity with the Howard Government was an emphasis on the economic costs of domestic violence, now estimated to be \$13.6 billion (KPMG 2009) as against $\$ 8.5$ billion in 2004 . The long-term (covering 12 years) and intergovernmental nature of the plan was seen as an important breakthrough. A community education foundation was established in Melbourne and a National Centre of Excellence in Sydney, the latter combining the previously separate clearing house functions for sexual assault and domestic violence research.

While these were some specific steps involving Commonwealth/State collaboration, with the abolition of the Select Council on Women's Issues there was no longer any governance arrangements in place to oversight the implementation of the National Plan (due to run until 2022). It had been the Select Council that had primary responsibility for driving its implementation. Moreover, as the treaty body responsible for CEDAW pointed out, there was insufficient intersection between the National Plan and other key Commonwealth-State agreements, such as that on homelessness (Harris Rimmer 2009; CEDAW 2013).

In an area where Australia had long lagged behind other democracies, Labor's paid parental leave scheme finally became operational from 1 January 2011. It consisted in 18 weeks of leave paid at the minimum wage; a 'use it or lose it' component of two weeks paternity leave became operational from January 2013. The latter was announced during the 2010 federal election and was appropriated from the Coalition's paid parental leave policy. The Coalition Shadow Minister, Dr Sharman Stone (2010), had emphasised that the Coalition was following Sweden, Iceland and Norway in this respect 
Some progress was also made under the Rudd and Gillard governments in addressing the issue of equal pay. There has been a persistent gender pay gap in Australia, despite early gains after the adoption of the equal remuneration principle in 1972 . Forty years later, in November 2012 there was still a 17.6 per cent gap in the ordinary hours earnings of male and female full-time workers (WGEA 2013). Most importantly, the Fair Work Act of 2009 introduced more effective equal remuneration provisions based on establishing an undervaluation linked or attributable to gender. A successful case was then brought by the Australian Services Union on behalf of community service workers, over 80 per cent of whom are female. In its first decision under the new provisions the Fair Work Commission confirmed that there was no requirement for applications to reference an explicit male comparator group, and recognised that impediments to collective bargaining can contribute to pay inequity.

In November 2011, the Gillard Government announced \$2 billion in funding to allow the Commonwealth to 'fund its share of any wage increases' awarded as a result of the equal pay case for community service workers (those working in crisis services, including women's refuges, and in disability services). It also announced funding to support moves towards equal pay in the predominantly female and very poorly paid childcare and aged care industries $(\$ 300$ million for childcare workers and $\$ 1.1$ billion for aged care workers). For example the Early Years Quality Fund for childcare workers was to raise the pay of childcare workers for two years, until an equal remuneration decision could be handed down by Fair Work Australia. Early childhood educators were earning only $\$ 19.00$ an hour. The conditions included childcare centres having an enterprise bargaining agreement in place for their staff, a condition the Coalition took exception to, calling it a 'union slush fund'.

In addition to the new equal remuneration provisions of the Fair Work Act, in the 2013 Budget four years funding was provided to establish a specialist Pay Equity Unit in the 
Fair Work Commission to undertake pay equity research relating to general wage reviews as well as individual equal remuneration cases. Its first research report was Equal Remuneration under the Fair Work Act 2009, an important resource for the preparation of future cases (Layton et al 2013).

Equal remuneration also featured as an important element of gender equality in the first object of the Workplace Gender Equality Act 2012. This Act renamed the previous Equal Opportunity for Women in the Workplace Agency, providing an expanded emphasis on equal opportunity for men in relation to their caring responsibilities as well as on providing assistance to employers to do gender pay gap analysis.

Under the Labor Governments, there was also a more positive approach to international gender equality standards than under the preceding Howard Government. Australia's obligations under the Convention for the Elimination of All Forms of Discrimination against Women (CEDAW), as well as other international human rights obligations were set out in the framework of the National Plan to Reduce Violence against Women and their Children referred to above. In another development, Australia at last acceded to the Optional Protocol to CEDAW and Australian women could make complaints under it from March 2009.

By contrast with domestic policy, a clear overall gender equality objective and policy framework had been adopted for international development assistance even before the arrival of the Rudd Government in 2007. AusAID had developed relatively strong gender expertise to underpin policy development and program evaluation. AusAID appointed a Principal Gender Advisor who was a thematic expert across the program, unusual for the APS. The Rudd Government built on this by appointing a career diplomat as Ambassador for Women and Girls to promote Australia's gender equality objectives in the region. Prime Minister Gillard also launched the landmark program Pacific Women Shaping Pacific Development at the Pacific Island Forum in October 2013. This was a 10- 
year \$320 million initiative to increase women's participation in leadership and decisionmaking roles, economic opportunities and protection from violence. Sydney talk-back radio broadcaster Alan Jones was responding to this announcement when he made his 'Women are destroying the joint' comment that triggered a huge social media response. Gillard also became a UN Millennium Development Goals Advocate, especially focusing on the education of girls, and launched the first ever UN International Day of the Girl in Australia.

On the other hand, the development of the National Plan of Action to implement UN Security Council Resolution 1325 (2000) on women in conflict and conflict resolution was a relatively slow process. Australia was the 38th country to develop a National Plan (out of 43 so far, plus the Pacific regional plan), eventually launching its Plan in 2012 (Commonwealth of Australia, 2012). This outlines how Resolution 1325 will be implemented in peacekeeping missions undertaken by Australia, including awareness of security threats to the female population and incorporation of women into peace processes. Australia has held two side events on the agenda thus far in its term as an elected member, but dropped the focus on women for the September Presidency to small arms. However, Australia has raised WPS issues in all parts of the Security Council's program of work in a consistent and constructive manner, such as country mandates and sanctions discussions.

Labor tackled gender equality issues in the Defence portfolio with a significant degree of courage. The gender challenges for Australia's military institutions in complying with international gender norms were made clear in the 2011-2012 'culture reviews' of the Australian Defence Force (ADF), investigating sexual and other forms of abuse and systemic issues affecting women as well as the overall work culture. The Defence Minister Stephen Smith ordered these wide-ranging reviews in response to incidents both at the Australian Defence Force Academy and on the Royal Australian Navy vessel, HMAS Success (Smith 2011; Smith 2012). He also proposed removing restrictions for 
women in frontline combat. Whereas Australia removed restrictions on combat-related employment in 2000, women were still restricted from 'combat duties' where the duties required a person to commit, or to participate directly in the commission of, an act of violence against an adversary in time of war. Australia still has a reservation to CEDAW relating to the exclusion of women from these duties. ${ }^{2}$

In area of women in public decision-making, Labor committed during the 2010 election campaign to a target of a minimum of 40 per cent representation of women on Australian Government boards by 2015 (Wong and Collins 2012). Senator Penny Wong was also very supportive of the Australian Stock Exchange's new gender diversity policy for boards and work by the Australian Institute of Company Directors in mentoring women for board appointments. In contrast, the Coalition accepts the 'business case for diversity', in that boards with 'a critical mass of women' perform better across a variety of indicators. However spokesperson Senator Michaelia Cash has also stated that '...the appointment of women to boards for reasons other than merit and excellence could be counterproductive and work against the long term interests of women. Quotas do not drive a positive change in thinking. Rather, they give board directors and businesses a box to tick off on regardless of the outcome' (Liberal Party of Australia, 2013).

Both the major parties were in favour of a focus on the 'financial inclusion' agenda at the G20 Summit to be held in Brisbane in November 2014. The G20 members have tasked the OECD and the World Bank to make progress in advancing financial inclusion, ensuring that women, as well as men, have access to and control over a full range of financial products (World Bank 2013).

\section{The Coalition's gender equality policies}

\footnotetext{
${ }^{2}$ Current as of 4 February 2014, http://www.un.org/womenwatch/daw/cedaw/reservations-country.htm
} 
At the federal government level, cross-government work on gender equality had been hindered under the Rudd and Gillard Governments by the location of the Office for Women in the line department of Family and Housing, Community Services and Indigenous Affairs, 20 kilometres away from the heart of government. In such circumstances early access to important Cabinet submissions may be dependent on good relationships rather than being an automatic part of the Cabinet process.

Moreover, as the 2013 Coalition women's policy stated, location in the Family and Community Services portfolio had implied that the women's portfolio was a welfare concern rather than underpinning a whole-of-government approach to improving government outcomes for women. This was why women's peak bodies had advocated a return of the women's portfolio to Prime Minister and Cabinet since its exile in 2004. However, such was the new Prime Minister's misogynist reputation and the reaction to the lack of women in his Cabinet that the return of women's policy to Prime Minister and Cabinet received a very mixed reception (Harris Rimmer 2013). The Destroy the Joint movement helped spread the word through Facebook and Twitter that the Prime Minister was now 'Minister for Women' and an electronic petition stating that this was unacceptable promptly gathered 10,000 signatures. EMILY's List used its new social media capability to create a meme: 'The new Minister for the Status of Women in his own words' which attracted 200,000 views.

Labor figures reacted to the announcement immediately. Frontbencher Tanya Plibersek stated that '[i]t doesn't matter where he [PM Abbott] puts the Office for Women if there is no room for women at his Cabinet table'. EMILY's List National Co-Convenor Tanja Kovac pointed out that the Minister Assisting the Prime Minister for Women, Senator Cash, was in the outer ministry. She did not mention that the Ministers for the Status of Women under the Rudd and Gillard Governments had also been in the outer ministry. Anne Summers was more nuanced - she said: 
Speaking as a former head of OSW (in the Hawke era), I applaud this move. However, we are not talking real estate here and location is not everything. The policy brief is what counts (Summers 2013b).

While the Coalition Women's Policy led with the commitment to the Office for Women, its only funding commitment was $\$ 1$ million for the White Ribbon Campaign, a men's campaign against gender-based violence. The Coalition did not support the Community Services Union's equal pay case nor the expenditure required to implement it. Nor did it support the Pay Equity Unit in Fair Work Australia, Following the change of Government the Coalition reversed the funding decisions intended to support equal pay in the social and community services sector, including the Early Years Quality Fund. In addition, a number of the employer bodies like the Australian Industry Group that had unsuccessfully opposed the equal pay case were seeking to remove the equal remuneration provisions of the Fair Work Act (AIG 2012: 83ff).

The Coalition also regarded the reporting requirements of the Workplace Gender Equality Act (WGEA), now including the gender pay gap, as part of the regulatory burden imposed on business. Initially it intended to remove a range of reporting requirements by April 2014 but a successful campaign, including key business figures as well as advocacy organisations, resulted in the withdrawal of the government's exposure draft.

But in May 2014 the Minister for Employment, Senator Eric Abetz, announced a review of $W G E A$ reporting requirements with a call for public submissions closing in July, including an option for employers of completing an online survey. In line with the 'red tape' agenda, the 'guiding questions' for submissions were skewed to costs at the expense of benefits. Changes to reporting requirements were to be announced by April 2015.

The Government was also reviewing its procurement procedures and the requirements for contract compliance, in existence since 1992. Moreover, the Government's Commission 
of Audit listed the Workplace Gender Equality Agency as among the statutory bodies that should be rolled back into departments. Both of these measures were identified as part of a red tape reduction strategy.

On the other hand, Abbott had been committed since his 2009 book Battlelines, to a relative generous form of paid parental leave, covering 26 rather than 18 weeks and at a replacement wage rather than the minimum wage, up to a ceiling of $\$ 75,000.00$ in payments. He took the policy to both the 2010 and 2013 elections, despite opposition from both economic dries and social conservatives within the Coalition (the latter seeing this as even greater discrimination against 'stay-at-home mums' than the less generous Labor policy). Opposition within government ranks as well as among cross-benchers in the new Senate forced the Prime Minister to water down his initial proposal, with a likely outcome of significant improvements to the existing Labor scheme through the addition of superannuation payments and an extension of the period covered to 26 weeks.

Despite ambivalent attitudes to gender equality policy at home, the Coalition expressed strong support for gender equality initiatives at the international and regional levels, and particularly initiatives to reduce gender-based violence. In December 2013 the Abbott Government appointed former Senator and Australian Democrats Leader Natasha Stott Despoja to the position of Ambassador for Women and Girls, a position initiated by Prime Minister Kevin Rudd. The restructure of the aid and foreign affairs portfolio and major cuts meant that the outcome for gender equality programs remained unclear. However, amidst the aid cuts, Minister Bishop on a visit to Port Moresby and Lae in February 2014 announced \$3 million in funding for a new Papua New Guinea Family and Sexual Violence Case Management Centre. Ms Bishop has also become a champion for the prevention of sexual violence in armed conflict, an initiative led by the UK Government. 


\section{Women's advocacy organisations}

One major initiative of the Rudd and Gillard Governments in the women's portfolio was to give voice back to government-funded peak bodies. Under the Howard Government so-called 'gag' clauses restricting media activity had been inserted into government funding contracts for the peak bodies funded to represent women to government. Soon after the Labor victory in 2007 Gillard, as Acting Prime Minister, gave a commitment to the Australian Council of Social Service to get rid of the gag clauses in government funding contracts and they were formally withdrawn a few months later. ${ }^{3}$ In 2013 , the Gillard Labor Government passed the Not-for-Profit Sector Freedom to Advocate Act in an attempt to prevent a future conservative government from reintroducing gag clauses. The Gillard Government had also enacted legislation in 2012-13 that spelled out that the governance standards required of charities must not prohibit advocacy. In line with the High Court AidWatch decision, this was statutory confirmation that advocacy should not be a reason to remove benefits such as tax deductible status.

The Rudd Government also reviewed the corporatist framework for the representation of women's views in existence since 1999. Initially this had consisted in the funding of three and then four peak bodies, when rural women successfully lobbied for their own peak body. There were no designated peak bodies, however, for Aboriginal or migrant women (WRANA 2005, 7).

In 2010 the Rudd Government created a new framework for representation of women's views to government; there were now six peak bodies including one representing Aboriginal and Torres Strait Islander Women and one representing Immigrant and Refugee Women. The largest of the funded peak bodies was the Equality Rights Alliance auspiced by the YWCA, with over 60 affiliated organisations, themselves often umbrella

\footnotetext{
${ }^{3}$ See for example, the letter sent by Minister Jenny Macklin to Women With Disabilities Australia on 4 April 2008.
} 
bodies or federations. Other 'Alliances' represented rural women and the issue areas of women's economic independence and violence against women. The evaluation framework for the women's Alliances made advocacy a defining principle of their activity. In line with the Labor Government's attempt to shore up their advocacy functions through the Not-for-Profit Sector Freedom to Advocate Act, there was a small increase in the second round of triennial funding for the Alliances in 2013.

In 2013 the new Minister Assisting the Prime Minister for Women, Senator Michaelia Cash, had extensive meetings with each of the funded Alliances both in Opposition and on taking government. She assured them of support but asked them for more tightly focused objectives. When she launched the first annual civil society report card on the National Action Plan on Women, Peace and Security in October 2013, she was enthusiastic about the role of women's advocacy organisations in developing and promoting the National Action Plan and holding the government to account for its implementation. The Coalition also continued funding community members on the Australian delegation to the Commission for the Status of Women in New York. On the other hand, The Coalition was committed to the closing down of the Gillard Government's Charities and Not-for-Profits Commission as an independent regulator, as part of its agenda for reducing red tape, so it was unclear whether the advocacy functions of organisations in receipt of government funding would continue to be protected.

\section{Parliamentary representation of women}

While Australian political parties have been moving away from women's policies, there have also been backwards trends in terms of the representation of women in politics and the kind of discourse directed at women political leaders, particularly when and if they raise issues of gender equality. For example, although Gillard long delayed raising gender issues, despite the sexual vilification she was being subjected to in social media and elsewhere, once she did so she was regarded as inciting a 'gender war' that 
rebounded on her leadership (Sawer, 2013; McLaren and Sawer 2014). Women Cabinet ministers who defended her were described by Opposition members as the "handbag hit squad', suggesting it was illegitimate for senior ministers to openly discuss sexism in politics and confirming received wisdom that women in public life will be penalised for doing so (Johnson 2012). This kind of reaction perhaps helps explain the failure discussed above to develop a clear gender equality policy framework.

In general, the series of Coalition election victories at State and then the federal level has contributed to an overall decline in women's parliamentary representation in Australia (dropping from 31 per cent in 2009 to 29 per cent by the end of 2013). The plateauing and then gradual slip in the presence of women in Australian parliaments (Figure 1) has contrasted with the significant increase in the parliamentary representation of women in many other democracies, due to more vigorous action including the introduction of legislated candidate quotas. Australia slipped from 15th place in 1999 in the international league table maintained by the Inter-Parliamentary Union to 43rd place in October 2013, with 48 countries above it.

Figure 1. Women as a percent of MPs across Australia since 2002

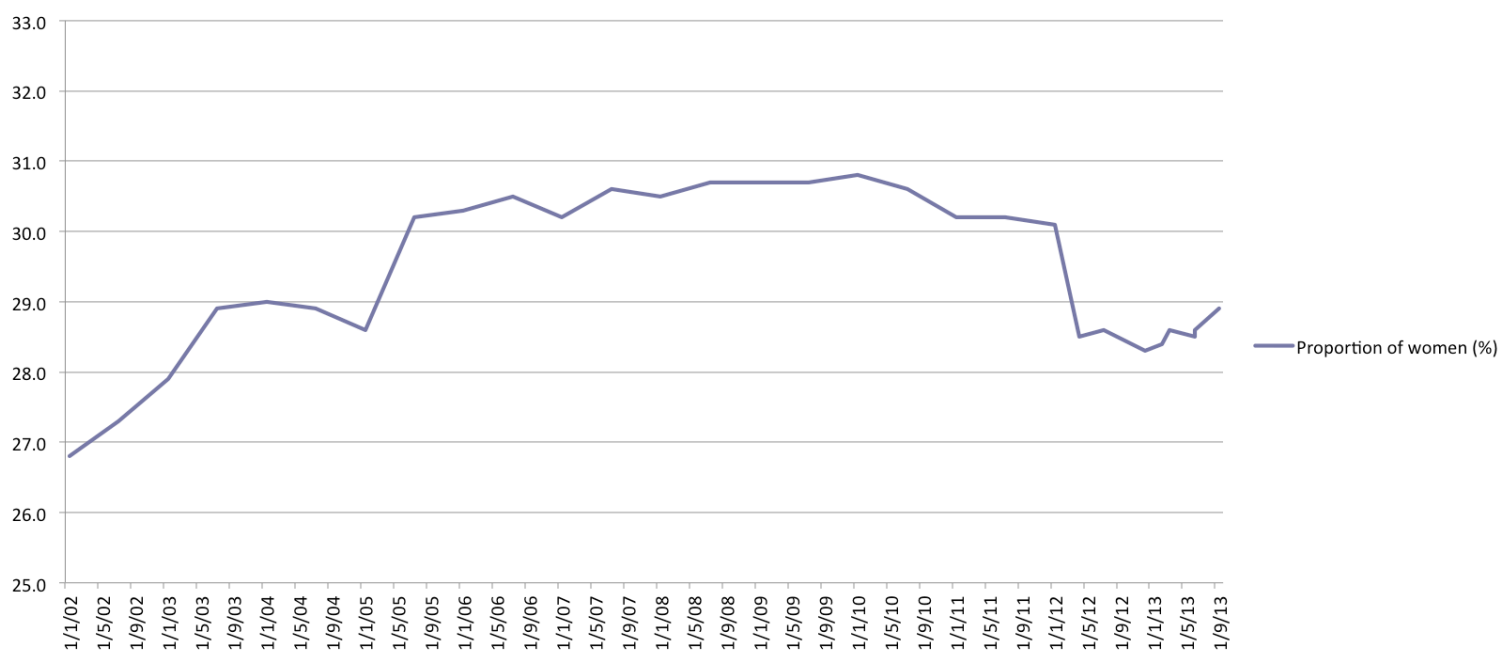

The continuing failure of the Coalition parties to field a significant number of women candidates has meant that incoming Coalition governments have an inadequate pool of 
women to draw on for front bench positions compared with Labor (Curtin and Sawer 2011, 50). For example, after the 2013 election women constituted 43 per cent of the Federal Labor Parliamentary Party, 21.6 per cent of the Liberal Parliamentary Party and 15.8 per cent of the Nationals Parliamentary Party. The number of women in Cabinet dropped from six to one.

There was a great deal of critical commentary when the Abbott Cabinet was revealed as having only one woman member, Foreign Minister Julie Bishop (Table 2). Media stories adversely compared Australia to many countries including Afghanistan. The extensive media criticism was reflected in the polls, although with a gender and partisan inflection. Essential Research found 51 per cent of women (but only 39 per cent of men) were concerned that there was only one woman in Cabinet; 90 per cent of Greens voters were concerned, compared with 67 per cent of Labor voters and only 17 per cent of Liberal voters (Crikey.com, 24 September 2013).

Abbot declared he was 'very disappointed there are not a lot more women in Cabinet', as though Cabinet appointments were not in the purview of Liberal Prime Ministers, and went on to claim that there were many women 'knocking on the door'. This led to some public discussion about whether the door was really open on the conservative side of politics, with outgoing Liberal parliamentarians such as Judi Moylan, Senator Sue Boyce and former Senator Judith Troeth identifying structural and cultural problems within the party.

Table 2: Gender breakdown of the Abbott Ministry and the Opposition Shadow Ministry, September 2013

\begin{tabular}{|l|l|l|l|}
\hline Ministry category & Male & Female & Female (\%) \\
\hline Cabinet & 18 & 1 & 5.3 \\
\hline Whole ministry & 25 & 5 & 16.6 \\
\hline Parliamentary secretaries & 11 & 1 & 8.3 \\
\hline Shadow Cabinet & 14 & 5 & 26.3 \\
\hline Shadow ministry & 19 & 11 & 36.7 \\
\hline Shadow parliamentary & 7 & 8 & 53.3 \\
\hline
\end{tabular}


secretaries

\section{Conclusions}

Why then does the evidence suggest that both the Labor and Coalition parties are now more comfortable in articulating broad gender equality objectives in the international realm, than in domestic economic and social policy? Bipartisan commitment on domestic policy is more likely to emerge on issues of sexual and gender-based violence rather than $\mathrm{n}$ broader issues of gender equality. We have identified eight possible explanations.

First, a focus on sexual violence can seem ideologically neutral in both the domestic and international policy realms - it can be read as paternalistic and protectionist on the one hand, or as liberationist and human rights focused on the other, and is often more focused on services to survivors than prevention. Trafficking has long been an issue that appeals to radical feminists and religious conservatives alike.

Second, a focus on regulating male violence can fit more easily with neoliberal agendas, because on the whole it does not require economic redistribution or labour market regulation.

Third, across-the-board gender audit of domestic policy draws unwanted attention to the gender outcomes of neoliberal reshaping of the welfare state. The kind of gender budgeting programs pioneered in Australia became unpopular because they highlighted the disparate gender impact of budgetary measures such as cuts to the public sector. Fourth, as seen in the intense reaction to Prime Minister Gillard's two speeches on sexism and gender equality, such issues were likely to be seen as vote losers in the domestic context.

Fifth, the explicit articulation of gender equality goals in the international arena is in part due to peer pressure from Australia's diplomatic partners the European Union and 
the Obama administration, and especially US foreign policy under Hillary Rodham Clinton.

Sixth, the realm of international policy has attracted talent from both parties. It is no accident that Julie Bishop and Tanya Plibersek chose the Foreign Affairs portfolio to make their mark. There is the ability to pursue a degree of policy creativity, as seen in the political work of Judith Troeth, Mal Washer, Claire Moore, Melissa Parke and Janelle Saffin.

Seventh, the cynic could suggest that signing international treaties or lending a name to international causes is both budget-neutral and good for a politician's legacy. There will be pressure on Julie Bishop as one of very few female Foreign Ministers to be a role model in this regard. Julia Gillard did not necessarily go looking for this role but grew more comfortable with it after her misogyny speech.

Finally, there is more pressure on particular gender issues at the international than on the domestic level, which may seem counter-intuitive in the context of normal electorate-based politics. The international development organisations are part of global policy federations and are better funded and more organised for targeted lobbying than the domestic women's sector. In contrast, the domestic peak bodies (the Alliances) are dominated by service organisations and more diverse in their priorities and interests, often lacking dedicated media and policy staff.

This could change if the 'modern gender gap' should grow wider, with women voters, particularly younger and university educated women, being to the left of their male peers. But at present, the future of women's policy in Australia is none too clear.

\section{References}

Andrew, Merrindahl. 2013. The institutional harvest: Women's services and women's policy agencies. In Sarah Maddison and Marian Sawer (eds) The Women's Movements in Protest, Institutions and the Internet: Australia in transnational perspective. London: Routledge, 87-104. 
Australian Council for International Development, WILPF, Australian National Committee for UN Women and Australian National University Gender Institute, Annual civil society report card on Australia's National Action Plan on Women, Peace and Security, August 2013, available at http://genderinstitute.anu.edu.au/sites/default/files/imce/Civil\%20Society\%20Report\% 20Card\%202013\%20FINAL\%20LORES.pdf

Australian Industry Group. 2012, Removing the Barriers to Productivity and Flexibility: Submission to the Fair Work Act Review. Available at:

http://www.aigroup.com.au/portal/binary/com.epicentric.contentmanagement.servlet.C ontentDeliveryServlet/LIVE_CONTENT/Policy\%2520and \%2520Representation/Submissio ns/Workplace\%2520Relations/2012/submission_FWA_Review_Feb2012.pdf

Chappell, Louise and Jennifer Curtin. 2013. Does Federalism Matter? Evaluating State Architecture and Family and Domestic Violence Policy in Australia and New Zealand. Publius 43(1): 24-43.

COAG Reform Council (CRC).), 2013. Tracking Equity: Comparing outcomes for women and girls across Australia. Sydney: CRC.

Curtin, Jennifer and Marian Sawer. 2011. Oceania. In Gretchen Bauer and Manon Tremblay (eds) Women in Executive Power: A Global Overview. London: Routledge, 4564.

Harris Rimmer, Susan, 2009. 'Grand Plans' Inside Story, 14 May available at http://inside.org.au/grand-plans/.

Harris Rimmer, Susan, 2010. 'Raising women up: analysing Australian advocacy for women's rights under international and domestic law' in Margaret Thornton and Trish Luker (eds) Sex Discrimination in Uncertain Times, ANU E-press.

Harris Rimmer, Susan. 2013. The distortion of Abbott's 'women problem'. Public Sector Informant, 4 October.

Harris Rimmer, Susan. 2013. 'Australian Leadership at the Security Council: Advancing the Women, Peace and Security Agenda' UNSW Human Rights Defender, July.

Inter-Parliamentary Union. 2014. Parline: Specialized Parliamentary Bodies. http://www.ipu.org/parline-e/Instancelist.asp

Johnson, Carol. 2012. Tony Abbott and women: How both sides have played the gender card. The Conversation, 8 October. URL: <http://theconversation.edu.au/tony-abbottand-women-how-both-sides-have-played-the-gender-card-10019>.

KPMG, 2009, The Cost of Violence against Women and their Children, Safety Taskforce, Department of Families, Housing, Community Services and Indigenous Affairs, Australian Government. 
Layton, Robyn, Meg Smith and Andrew Stewart. 2013. Equal Remuneration under the Fair Work Act 2009: A Report for the Pay Equity Unity of the Fair Work Commission. Available at: http://www.fwc.gov.au/documents/payequity/ER-report-6-Dec-2013.pdf

Liberal Party of Australia. 2012. Women in Business - cultural change not quotas. Media Release. Available at https://www.liberal.org.au/latest-news/2012/11/27/womenbusiness-\%E2\%80\%93-cultural-change-not-quotas

McBride, Dorothy E. and Amy G. Mazur. 2010. The Politics of State Feminism: Innovation in comparative research. Philadelphia: Temple University Press.

McLaren, Kirsty and Marian Sawer. 2014. The 2013 election and the Abbott 'mandate'. In John Wanna and Carol Johnson (eds) Abbott's Revenge: The 2013 Federal Election Election, forthcoming, Canberra: ANU Press.

Mapping the Australian Women's Movement (MAWM). 2013. The Institutional Harvest: Women's services and agencies in Australia 1970-2013. Available at: http://institutionalharvest.net

National Council to Reduce Violence against Women and their Children. Time for Action: The National Council's Plan for Australia to Reduce Violence against Women and their Children 20092021, Government Publishing, Canberra 2009.

Sawer, Marian. 2007. Australia: The Fall of the Femocrat, in Joyce Outshoorn and Johanna Kantola (eds), Changing State Feminism, Basingstoke: Palgrave Macmillan, pp. 20-40.

Sawer, Marian. 2013. Misogyny and misrepresentation: Women in Australian parliaments. Political Science 65(1): 105-117.

Smith, Stephen (Minister for Defence), Government response to the review into allegations of sexual or other forms of abuse in Defence, 26 November 2012, available at http://www.minister.defence.gov.au/2012/11/26/minister-for-defence-government-response-tothe-review-into-allegations-of-sexual-or-other-forms-of-abuse-in-defence/, accessed 12 January 2013.

Smith, Stephen (Defence Minister). Ministerial press releases, 11 April 2011, http://www.minister.defence.gov.au/2011/04/11/sex-discrimination-commissioner-to-lead-reviewof-the-australian-defence-force-academy-and-the-australian-defence-force/, and 6 May 2011, http://www.minister.defence.gov.au/2011/05/06/reviews-into-the-australian-defence-forceacademy-the-australian-defence-force-and-defence-culture/, both accessed 30 January 2013.

Stone, Sharman, 2010. Second Reading Speech on the Paid Parental Leave Bill 2010, House of Representatives Debates, 27 May: 4383-4. 
Summers, Anne. 2013a. The Misogyny Factor. Sydney: NewSouth Publishing.

Summers, Anne. 2013b. Australia's new PM for Women has a lot to learn. The Drum, 20 September.

Lamont, Leonie 2011. 'Labor vows to help women get runs on boards' Sydney Morning Herald, 7 September, available at http://www.smh.com.au/executive-style/executivewomen/labor-vows-to-help-women-get-runs-on-boards-20110906-

1jvyf.html\#ixzz2sKRCNYGQ.

Trenoweth, Samantha ed. 2013. Bewitched \& Bedevilled: Women write the Gillard years. Melbourne: Hardie Grant Books.

Women's Rights Action Network Australia (WRANA). 2005. Australian NGO Shadow Report on the Implementation of the Convention on the Elimination of All Forms of Discrimination against Women. Prepared by WRANA with the endorsement of 101 organisations. Melbourne: WRANA.

Wong, Senator The Hon Penny and Julie Collins MP, 2013. 'Joint Media Release: Labor Achieves Record Level of Women's Representation on Australian Government Boards', 5 August, available at http://www.pennywong.com.au/media-releases/labor-achievesrecord-level-of-womens-representation-on-australian-government-boards/

Workplace Gender Equality Agency (WGEA). 2013. Gender pay gap statistics. Available at: http://www.wgea.gov.au/sites/default/files/2013-02-

Gender\%20pay\%20gap\%20statistics.pdf

World Bank and OECD, 2013. Women and Finance: Progress Report to the G20. Available at https://www.g20.org/sites/default/files/g20_resources/library/G20_Women_and_Finance_Progres s_report_WB_and_OECD.pdf.

\section{Primary Sources}

CEDAW (Committee on the Elimination of Discrimination against Women). 2013. Response to Australian Follow-Up, 3 September. Available at:

http://tbinternet.ohchr.org/Treaties/CEDAW/Shared\%20Documents/AUS/INT_CEDAW_FUL_AUS 15067 E.pdf

Commonwealth of Australia, National Plan to Reduce Violence against Women and their Children 2010 - 2022, March 2012, available at http://www.fahcsia.gov.au/sites/default/files/documents/05_2012/national_plan.pdf, accessed 26 February 2013.

Commonwealth of Australia, Australian National Action Plan on Women, Peace and Security 20122018, March 2012, available at http://www.fahcsia.gov.au/sites/default/files/documents/05_2012/aus_nap_on_women_2012_20 18.pdf, accessed 15 January 2013. 
Convention on the Elimination of All Forms of Discrimination against Women, adopted 18 December 1979, entered into force 3 Sept. 1981, G.A. Res. 34/180, 34 UN GOAR, Supp. (No. 46), UN Doc. A/34/46, at 193 (1979), 1249 U.N.T.S. 14. 